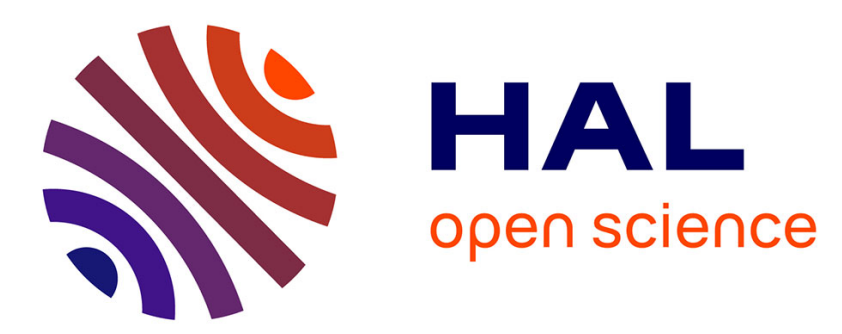

\title{
Author's personal copy Green corridors in urban landscapes affect the arthropod communities of domestic gardens
}

Alan Vergnes, Isabelle Le Viol, Philippe Clergeau

\section{- To cite this version:}

Alan Vergnes, Isabelle Le Viol, Philippe Clergeau. Author's personal copy Green corridors in urban landscapes affect the arthropod communities of domestic gardens. Biological Conservation, 2011, 1, pp.171-178. 10.1016/j.biocon.2011.11.002 . hal-01086060

\section{HAL Id: hal-01086060 https://hal.science/hal-01086060}

Submitted on 21 Nov 2014

HAL is a multi-disciplinary open access archive for the deposit and dissemination of scientific research documents, whether they are published or not. The documents may come from teaching and research institutions in France or abroad, or from public or private research centers.
L'archive ouverte pluridisciplinaire HAL, est destinée au dépôt et à la diffusion de documents scientifiques de niveau recherche, publiés ou non, émanant des établissements d'enseignement et de recherche français ou étrangers, des laboratoires publics ou privés. 
Provided for non-commercial research and education use. Not for reproduction, distribution or commercial use.

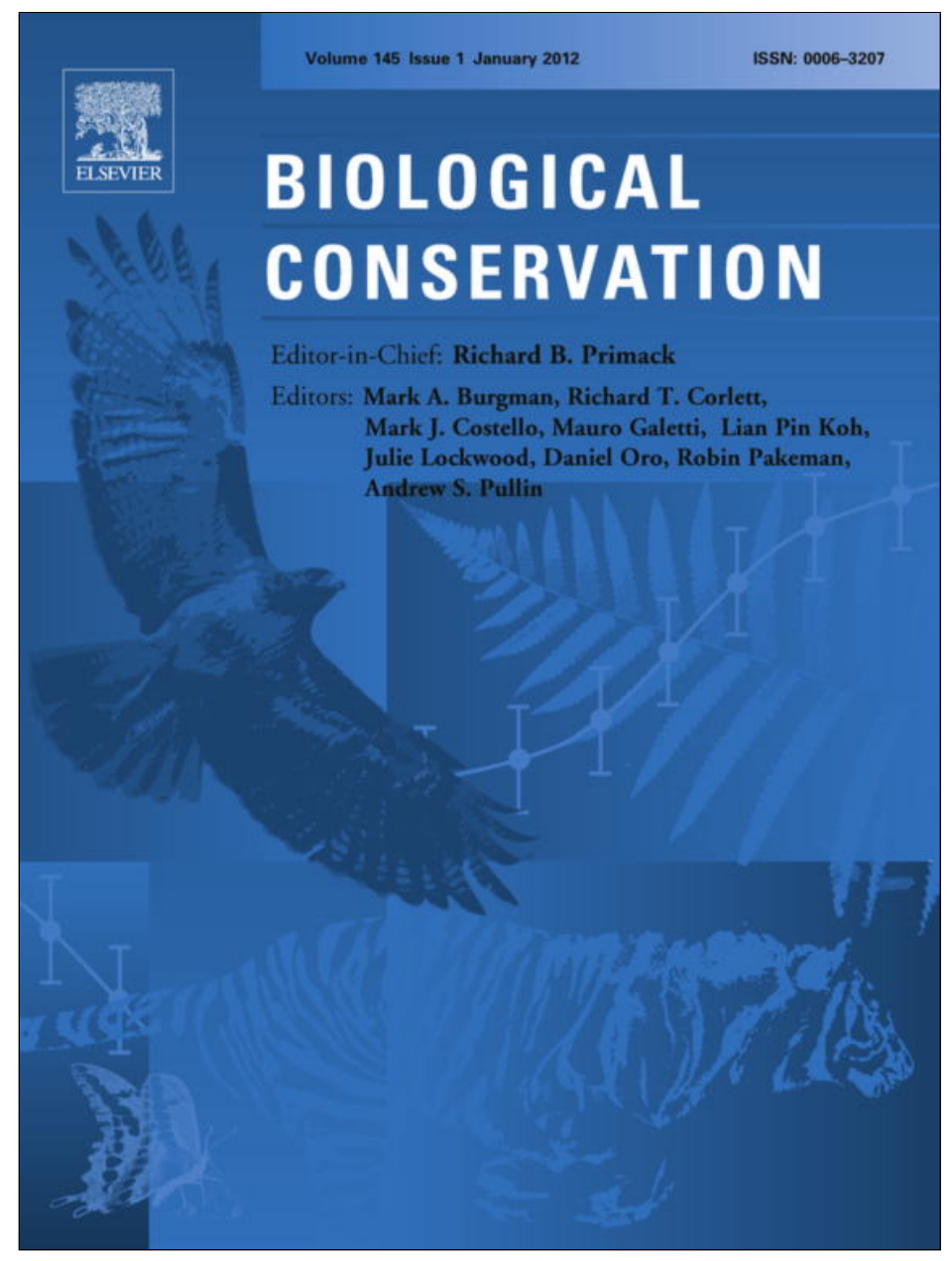

This article appeared in a journal published by Elsevier. The attached copy is furnished to the author for internal non-commercial research and education use, including for instruction at the authors institution and sharing with colleagues.

Other uses, including reproduction and distribution, or selling or licensing copies, or posting to personal, institutional or third party websites are prohibited.

In most cases authors are permitted to post their version of the article (e.g. in Word or Tex form) to their personal website or institutional repository. Authors requiring further information regarding Elsevier's archiving and manuscript policies are encouraged to visit:

http://www.elsevier.com/copyright 


\title{
Green corridors in urban landscapes affect the arthropod communities of domestic gardens
}

\author{
Alan Vergnes*, Isabelle Le Viol, Philippe Clergeau \\ Muséum National d'Histoire Naturelle, Département d'Ecologie, UMR CERSP, 55 rue Buffon, 75005 Paris, France
}

\section{A R T I C L E I N F O}

\section{Article history:}

Received 30 June 2011

Received in revised form 25 October 2011

Accepted 2 November 2011

Available online 26 November 2011

\section{Keywords:}

Arthropods

Domestic garden

Carabids

Corridors

Fragmented landscape

Metacommunities

Spiders

Staphylinids

Urban ecology

\begin{abstract}
A B S T R A C T
Ecological corridors are landscape elements that prevent the negative effects of fragmentation. However, their effectiveness has never been clearly validated in urban landscapes.

We analysed the role of green corridors in an urban context by comparing metacommunities of arthropods in (i) woodlots considered as sources of species, (ii) woody corridors and domestic gardens that are (iii) connected (CG) or (iv) disconnected to corridors (DG) and taking into account the connectivity of the matrix. We trapped 3 taxa of arthropods - spiders, carabids and staphylinids - because they are sensitive to fragmentation but with different dispersal capabilities. We analysed their species richness, abundance and taxonomic and functional composition.

For the 3 taxa, the taxonomic and functional compositions of communities in CG were closer to those of the corridor and the source than those of DG. Woodland species were associated with source, corridor and CG. A lower abundance in DG was revealed for staphylinids and spiders. Lower species richness in DG was observed for staphylinids.

The differences between taxa could be explained by the dispersal capabilities of the species and by their various responses to landscape structures. For carabids, processes at a wider scale could be responsible for their rarity in sources and, consequently, in gardens. For spiders, the colonisation from other sources could explain the high species richness found in disconnected gardens.

Our results suggest that the role of corridors is crucial for enhancing biodiversity in green spaces such as domestic gardens. Our results clarify the effectiveness of corridors in urban landscapes and have direct implications for the ecological management of cities.
\end{abstract}

(C) 2011 Elsevier Ltd. All rights reserved.

\section{Introduction}

In urban landscapes, fragmentation, usually considered as a major threat to biodiversity, dramatically affects landscape structure and decreases landscape connectivity (Hamer and McDonnell, 2008; McGarigal and Cushman, 2002; McKinney, 2008; Pauchard et al., 2006). Generally, the remaining woodland habitats in cities, called green spaces (Smith et al., 2006a), are physically distant from each other and are isolated by a hostile matrix composed of buildings and streets (Collinge, 1996; Gibb and Hochuli, 2002). Thus, fragmentation limits the dispersal of many species and strongly shaped metacommunities sensu (Wilson, 1992), i.e. potentially interacting species linking via dispersal (Hubbell, 1997; Leibold et al., 2004; McKinney, 2006; Rosindell et al., 2011).

Indeed, in more natural landscapes, ecological corridors are an effective strategy to limit biodiversity decline within fragmented woodland habitats (Bailey, 2007; Gilbert-Norton et al., 2010). Consequently, the protection of corridors and green frameworks is a

\footnotetext{
* Corresponding author. Tel.: +33 140795765; fax: +33 140793835.

E-mail address: alan.vergnes@gmail.com (A. Vergnes).
}

major objective of landscape management policies (Jongman et al., 2004). In urban landscapes, the development of woody corridors could be an interesting way to limit fragmentation and enhance "ordinary biodiversity" as desired by citizens (Ahern, 2007; Blair and Johnson, 2008; Savard et al., 2000). In fact, matrix properties and the use of corridors in cities are different than in more natural landscapes, and previous results cannot be easily applied in urban areas. The effects of ecological corridors in an urban context need to be properly tested (Clergeau, 2007; Gilbert-Norton et al., 2010).

The aim of this study is to assess the effectiveness of corridors in suburban landscapes using arthropod metacommunities of urban domestic gardens. Although domestic gardens are small in area, they are numerous, and they represent a significant proportion of green space area in cities (Goddard et al., 2010; Loram et al., 2007). The potential role of domestic gardens in urban conservation has been shown by recent studies (Davies et al., 2009; Loram et al., 2007). However, the mechanisms responsible for the structure of communities in gardens have not been clearly identified.

It is urgent to better understand the importance of dispersal in the structuring of communities and, thus, in the functioning of 
metacommunities (Holyoak et al., 2005). To this aim, a comparison of community responses to landscape structure using different taxa with different dispersal behaviours should be meaningful (Fattorini, 2011; Le Viol et al., 2008; Schweiger et al., 2005). Thus, we focused our study on 3 major taxa of arthropods: spiders, carabids and staphylinids (Didham et al., 2010; McIntyre et al., 2001). As these species vary in preferences for habitat and in dispersal capabilities, the community properties of these three taxa are indicative of both local and landscape modifications. Some carabids (Chapman et al., 2005; Joyce et al., 1999) and staphylinids (Markgraf and Basedow, 2002; Tomlin et al., 1992) were able to disperse several kilometres by flying and some spider species up to tens of kilometres using their silk (Bell et al., 2005). Some species (mainly woodland species for carabids and staphylinids), were ground dwelling and thus are extremely sensitive to physical barriers such as road or buildings (Desender et al., 2005; Mader et al., 1990). Moreover, they are located at an intermediate level on food webs: as predators of smaller arthropods (Good and Giller, 1991; Griffiths et al., 2007; Nyffeler and Sunderland, 2003) and prey for vertebrates (Deichsel, 2006; Thomas et al., 2001) and thus have a major ecological function.

To analyse the effectiveness of corridors, we compared the richness, abundance, taxonomic and functional composition of metacommunities in woodlots considered as a source, woody corridors linked to the sources, and hedgerows of two types of gardens - disconnected from (DG) or connected (CG) - to the corridor. We then focused our analyses on gardens to control for effects of local variables and landscape variables. As the measure of landscape connectivity should not be limited to corridors (Gaublomme et al., 2008; Lizée et al., 2011; Prevedello and Vieira, 2010), we also took into account the properties of the matrix surrounding the gardens.

\section{Materials and methods}

\subsection{Study area and sampling design}

To test the effectiveness of woody corridors in gardens within urban matrices, we defined a strict sampling design at four urban sites (s01 to s04) located around Paris (see Fig. 1). The four sites have been selected regarding to their landscape configuration. Indeed, each site was composed of an urban matrix composed of a mosaic of roads and small detached houses with domestic gardens, a unique urban woodlot (park or wood up to $150 \mathrm{ha}$ ) in a $1.5 \mathrm{~km}$ radius that was potentially the only source for arthropods (Chave, 2004), to avoid the effect of uncontrolled potential sources of arthropods, and a woody corridor (between 20 and $50 \mathrm{~m}$ wide) (Davies and Pullin, 2007).

Within each urban matrix, we selected two types of gardens. First, we selected four connected gardens (CG) contiguous or less than $10 \mathrm{~m}$ from the corridor. Two CG were located between 20 and $300 \mathrm{~m}$ from the source and two were located between $500 \mathrm{~m}$ and $1025 \mathrm{~m}$. As a control (Gilbert-Norton et al., 2010), we also selected four gardens located more than $300 \mathrm{~m}$ from corridor and defined as disconnected gardens (DG). To avoid the correlation between the distance to source and the type of garden, we selected DG located at the same distance from sources. We also checked for correlation using Mann-Whitney test, $W=377.5, p=0.07$ ) and using site as a random effect in a generalised linear mixed models (Distance to woodlot $\sim$ connection to corridor + site, $\beta=0.07$ $(\mathrm{SE}=0.22), p=0.73$ ).

In all sites, the dominant vegetation of the woodlots and corridors is mixed deciduous and is dominated by native oaks (Quercus spp). The lower strata of vegetation are mainly composed of Rubus fructicosus and Hedera sp. All gardens have hedgerows.

Thus, we sampled metacommunities of arthropods simultaneously in four sources, four corridors, sixteen CG, and sixteen DG (Fig. 1).

Arthropods were sampled using pitfall traps of $8.5 \mathrm{~cm}$ wide in diameter, $10 \mathrm{~cm}$ deep and contained a non attractive preservative (ethylene glycol). They were settled with a minimum of $5 \mathrm{~m}$ between traps. At each site, we set one station of four traps within the source, three stations of three traps within the corridor. In gardens we only set one station of two traps under hedgerows as it was difficult to set more traps separated under hedgerows. A total of 116 traps were laid for this study. Arthropods were trapped continuously from May to July 2009 (all traps were emptied once after 3 weeks).

(A)

(B)

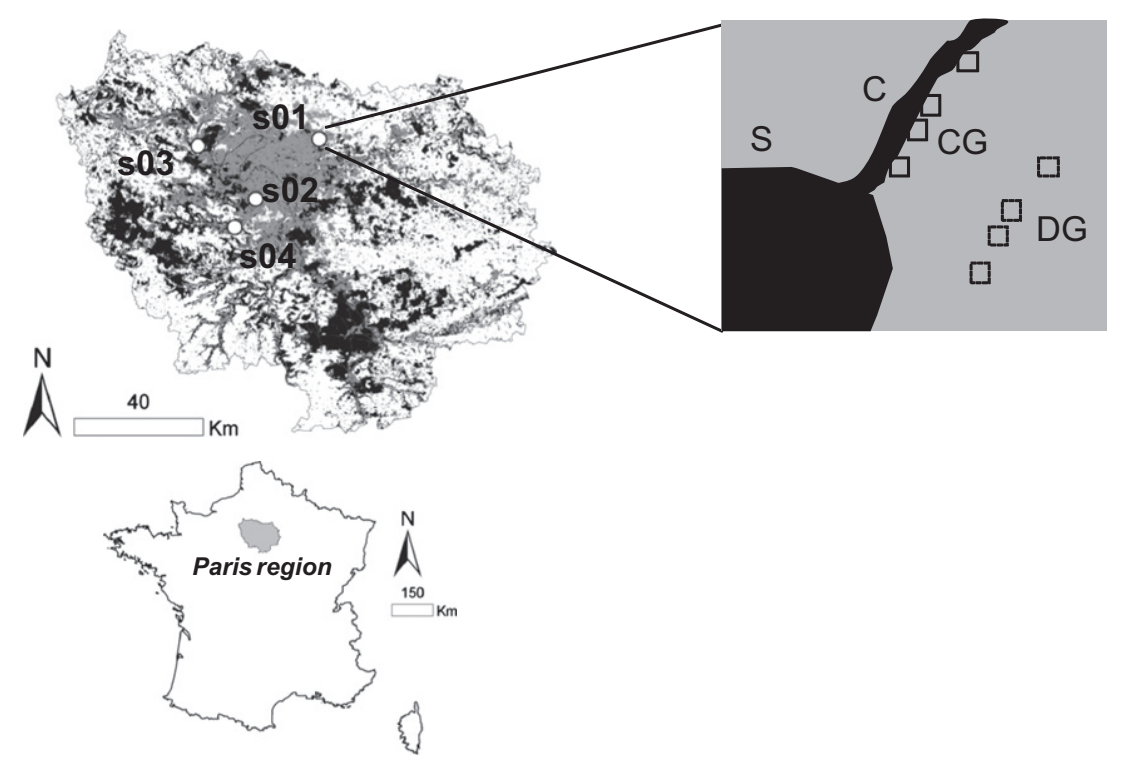

Fig. 1. Map of the Paris region showing urban sites (A) and schema of the sampling design (B) of a site. (A). Open and rural land cover are presented in white. Woodlands are represented in black. Urban cover is represented in grey. Sites are indicated by white circles (s01 to s04). (B) A site is composed of 4 green space types: a source (S), a corridor (C), 4 connected gardens (CG) and 4 disconnected gardens (DG). 


\subsection{Identification and species attributes}

Adult arthropod species were identified using classical keys. As immature arthropods are difficult to identify, they were not considered in our analyses, and Atheta species (Family Aleocharinae, staphylinids) were considered as Aleo. spp.

We recorded two functional traits: dispersal mode and habitat affinity. We defined two classes for the dispersal mode: (1) nonaerial dispersal and (2) aerial dispersal. We also defined three classes for habitat affinity to woodlands: (1) specialist open land species and generalist species that are more abundant in open land habitats, (2) generalist species without habitat focus and (3) generalist species more abundant in woodland and specialist species of woodlands. For carabids and staphylinids, the classifications followed Deichsel (2006) and were completed respectively by Ribera et al. (2001) and through interviews with specialists (Tronquet, pers. com). For spiders, high dispersal capability correspond to aerial dispersal using silk, also know as ballooning and species listed in Bell et al. (2005) were considered as aerial dispersers. For spiders, habitat affinity was coded following Harvey et al. (2002) and completed by Entling et al. (2007). Details of traits are given in Supplementary Material 1.

\subsection{Environmental variables}

Within each site, we measured at the landscape scale, we measured the connection to the corridor (CG/DG) and the distance between garden and source (Dist) (Smith et al., 2006a). We also described the matrix surrounding gardens. From a normalised difference vegetation index (NDVI, resolution of $15 \mathrm{~m}, 11$ classes of land uses), considered as a relevant descriptor of urban landscapes (Kerr and Ostrovsky, 2003; Yuan and Bauer, 2007), we considered three land use classes: build surface, gardens and woodlands. Using FRAGSTATS software (McGarigal, 2002), we characterised the composition and the configuration of the landscape surrounding each garden by calculating several metrics in a circular buffer of $200 \mathrm{~m}$ centred on gardens (excluding source and corridor). We measured four metrics for each of the three land use classes: percentage of the class in the buffer (per), patch density which measured the fragmentation (FRAG), area-weighted mean patch fractal dimension which measured the patch shape complexity (FRACTAL) and the aggregation index that measured the structural connectivity (AI). These twelve metrics were synthesised in a connectivity matrix index (CMI) using a PCA (coordinates of sites in axis $1,54.84 \%$ of the total inertia) (Supplementary materials 3 for details).

At the local scale, we measured sixteen variables (vegetation cover, soil features, hedgerows, surfaces, and management (Supplementary material 2 ). None of these variables were correlated to the type of garden (Supplementary materials 2). Using the same method than for matrix description, we tried to find a synthetic variable of the local scale but as in other studies on gardens, we failed (Smith et al., 2006a). Thus we retained the vegetation cover because it was correlated with many variables (Supplementary material 3). Moreover, vegetation cover is known to strongly affect arthropod composition in woody habitats (Magura et al., 2008; Small et al., 2006) and is an important feature of domestic gardens (Smith et al., 2006b). Note that vegetation cover under hedgerow (Veg) was described for a $4 \times 4 \mathrm{~m}$ square around each trap and was classified into five categories $(0-10 ; 11-25 \%, 26-50 \%, 51-$ 75\%, 76-100\%).

\subsection{Statistical analysis}

We analysed the metacommunities of arthropods by considering three complementary approaches. First, we analysed species richness (SR) and abundance (AB). Next, we made a more accurate analysis using taxonomic composition and finally, we analysed the functional composition of the metacommunities using habitat affinity and dispersion traits.

For each approach, we made two distinct analyses. First, we ran a global analysis comparing all types of green spaces. Second, we ran a specific analysis on gardens (hereafter called garden analysis) to verify the effects of the connection to the corridors, the CMI, the distance to the source, and accounting for vegetation cover (Gilbert-Norton et al., 2010). After measure of data and prior to garden analysis, we checked for relationship between all variables used in models (Supplementary material 2). To take into account the difference in sampling effort between the different types of green spaces, all analyses were computed at the trap level.

\subsubsection{Species richness and abundance}

The species richness and abundance of arthropods were analysed with generalised linear mixed models (GLMM) with a link $\log$ function and a Poisson error structure, relevant for count data (Bolker et al., 2009). According to the nested structure of our sampling design (stations within sites), we treated the site variable as a random effect (Noda, 2004), while the other explanatory variables were treated as fixed effects. We used a hypothesis approach for each step of analyses (Faraway, 2006). The analyses were computed with R 2.7.0 software and the lme4 package (Bates and Maechler, 2009).

\subsubsection{Taxonomic and functional composition}

We analysed analyse the effect of corridor on the taxonomic and functional composition of the arthropods using a partial Redundancy Analysis (pRDA). pRDA is a constrained ordination method related to principal components analysis which that allows community composition to be related to environmental variations (Legendre and Anderson, 1999). As a partial method, it can be used to remove the effect of covariables. In our case we used the geographical coordinates of sites ( $x_{-}$coord, $y_{-}$corrd) to correct for spatial correlation. For taxonomic composition analysis, data were transformed using the Hellinger distance to limit the weight of rare species and of the double - absence of species (Legendre and Gallagher, 2001).

Functional composition was handled using pRDA with the same covariable and a community weighted trait matrix as response variable (CWM) (Lavorel et al., 2008).

As pRDA was sensitive to rare species, we did not retain species observed once (singletons). ANOVA-like permutation tests $(n=999)$ were conducted to assess significance of the all analysis and for each term of the model.

\section{Results}

\subsection{Species richness and abundance}

Across the 4 sites, we captured 1262 adult individuals of spiders, 398 of carabids and 1446 of staphylinids, representing, respectively, 75, 25 and 61 species. The most abundant species were Lepthyplantes flavipes (23.14\%), Ozyptila praticola (12.68\%) and Zodarion italicum (6.10\%) for spiders; Nebria brevicollis (22\%), Notiophilus rufipes (25\%) and Harpalus atratus (10\%) for carabids; and Aleo. spp (40\%), Anotylus inustus (12\%) and Platarea brunnea (10\%) for staphylinids.

Using GLMM, we found an effect of the green space type for staphylinids and spiders. We observed lower species richness within the DG for staphylinids than within the other green spaces (sources, corridors and CG) and a lower abundance within the DG for staphylinids and spiders (Table 1). 
Table 1

Generalised linear mixed models (GLMMs) showing the differences between sources and the other green space types in term of species richness (SR) and abundance (AB) using site as a random effect. For SR and $A B, \beta$ and SE were transformed into mean species richness per trap and mean abundance with SE per trap using an exponential function, and significance levels were given (denoted ${ }^{*} p \leqslant 0.05,{ }^{* *} p \leqslant 0.001,{ }^{* * *} p \leqslant 0.001$ ). Connected gardens (CG), Disconnected gardens (DG).

\begin{tabular}{|c|c|c|c|c|c|c|}
\hline & \multicolumn{2}{|l|}{ Spiders } & \multicolumn{2}{|l|}{ Carabids } & \multicolumn{2}{|l|}{ Staphylinids } \\
\hline & SR (SE) & $\mathrm{AB}(\mathrm{SE})$ & SR (SE) & $\mathrm{AB}(\mathrm{SE})$ & SR (SE) & $\mathrm{AB}(\mathrm{SE})$ \\
\hline Sources & $5.71(1.24)$ & $13.3(1.31)$ & $1.31(1.38)$ & $1.5(1.84)$ & $3.32(1.3)$ & $11.82(1.47)$ \\
\hline CG & $4.94(1.13)$ & $10.96(1.15)$ & $1.58(1.22)$ & $2.19(1.42)$ & $3.32(1.16)$ & $11.16(1.24)$ \\
\hline DG & $4.09(1.14)$ & $6.5(1.16)$ & $1.16(1.24)$ & $1.84(1.43)$ & $1.29(1.21)^{* * *}$ & $3.87(1.26)^{* * * *}$ \\
\hline Corridors & $4.52(1.14)$ & $9.33(1.18)$ & $1.25(1.24)$ & $1.68(1.48)$ & $3.03(1.18)$ & $11.14(1.27)$ \\
\hline
\end{tabular}

For garden analysis, the abundance was significantly lower in the DG for spiders and staphylinids (respectively $\beta=-0.49$ ( $\mathrm{SE}=0.23), p=0.03$ and $\beta=-0.98(\mathrm{SE}=0.32), p=0.002)$. Species richness was also significantly lower in DG for staphylinids $(\beta=-0.67$ (SE $=0.17), p \leqslant 0.001)$. The abundance of carabids significantly decreased with the distance to source $(\beta=-1.01$ $(\mathrm{SE}=0.42), p=0.02)$ and was affected by vegetation cover $(\beta=1.52(\mathrm{SE}=0.4), p \leqslant 0.001)$. For carabids, we found a significant negative effect of distance to source $(\beta=-0.46(\mathrm{SE}=0.20), p=0.02)$ and a positive effect of CMI on species richness.

\subsection{Taxonomic composition}

As shown by pRDA, corridors, sources, CG and DG supported significantly different metacommunity compositions of spiders, carabids and staphylinids ( $p<0.01$ for the 3 taxa). However, the metacommunities in the CG were close to the metacommunities of the corridors (Fig. 2). The garden analyses (Table 2 and Fig. S1) confirmed that the difference between CG and DG was mainly due to the connection with the corridor. CMI was significant for carabids and staphylinids whereas the distance to source was significant only for carabids.

The pRDA (Fig. 2) showed that the spider species Diplocephalus picinus (Diplopic) and Diplostyla concolor (Diplcon) were more associated with sources whereas Trachyzelotes pedestris (Traped), Tenuiphantes flavipes (Tenfla) and Z. italicum (Zodita) were associated with the corridors and CG. DG were associated with Troxoch- rus scabriculus (Troxsca) and Erigone dentipalpis (Eriden). For carabids, we observed that Abax parallelepipedus (Abapar), Calathus fuscipes (Calruf) and Pterostichus madidus (Ptemad) were associated with sources whereas N. brevicollis (Nebbri), Harpalus rufipes (Harruf), $N$. rufipes (Notruf) were associated with the corridor and the CG. H. atratus (Haratr) were the only species associated with DG. For staphylinids, we observed that A. inustus (Anoinu) and Plataraea brunnea (Plabru) were more associated with sources whereas Anthobium atrocephalum (Antatro) and Omalium rivulare (Omariv) were associated with corridors and CG. Aleo. spp was the only species associated with DG.

The garden analysis confirmed the association between the previous species and the different garden type (Fig. S1).

\subsection{Functional composition}

For carabids, staphylinids and spiders, we found a significant relationship between species traits and environmental variables (Fig. 3) (respectively $p \leqslant 0.01, p \leqslant 0.01$ and $p \leqslant 0.05$ ). The green space type influenced the distribution of species according to their habitat affinity. For spiders, we observed that sources, characterised by a community with high affinity to woodlands, were separated from the CG, DG and corridors. For carabids and staphylinid, sources, corridors were at the extremity of a gradient representing the decrease of the affinity to woodland habitat and the increase of the dispersal capabilities. DG were at the other extremity of this gradient and were functionally characterised by
$(A)$ *

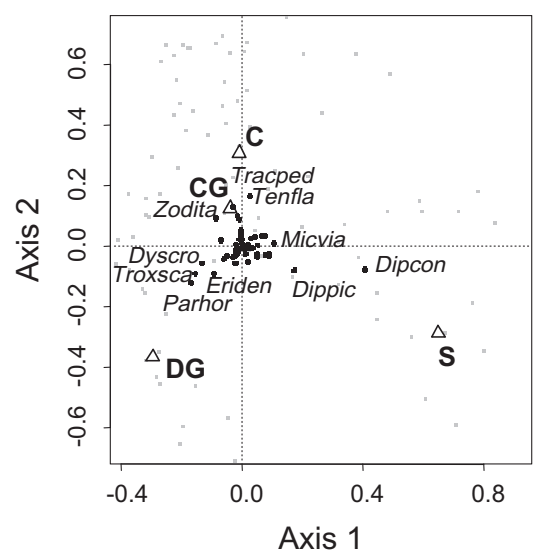

(B) **

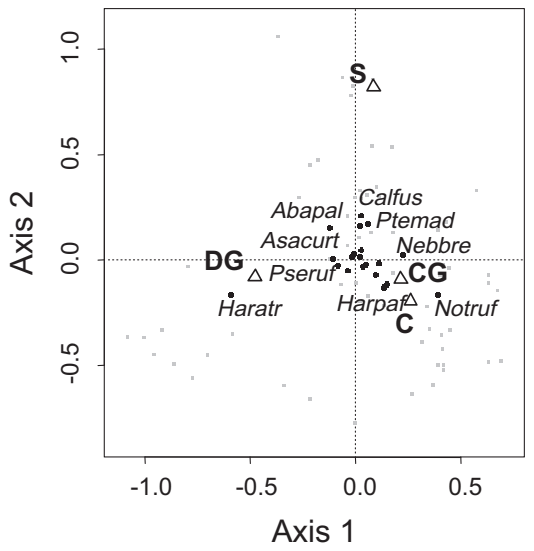

(C) **

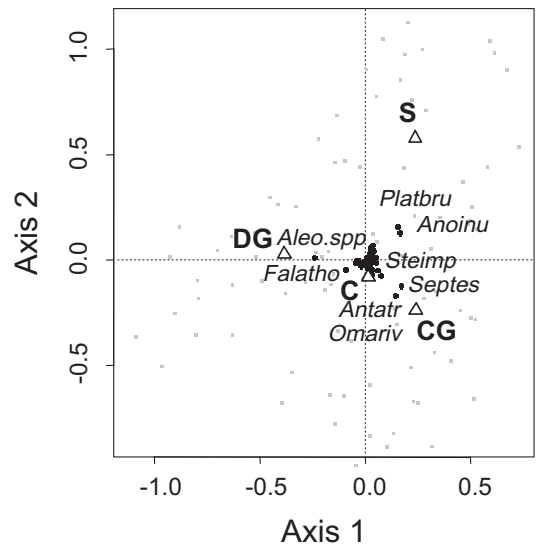

Fig. 2. Ordination diagram (biplot) from partial Redundancy analysis (pRDA) of spider (A), carabid (B) and staphylinid (C) metacommunities. For global analysis, we considered all type of green spaces (white triangle): source (S), corridor (C), connected garden (CG) and disconnected garden (DG). P values are represented for each axis and for each taxa (denoted ${ }^{* *} p \leqslant 0.01$ ). Traps are represented by grey dots. Species are represented by black dots [for spiders: Diplostyla concolor (Dipcon), Dysdera crocata (Dyscro), Erigone dentipalpis (Eriden), Microneta viaria (Micvia), Pardosa hortensis (Parhor), Tenuiphantes flavipes (Tenfla), Trachyzelotes pedestris (Traped), Troxochrus scabriculus (Trosca), Tenuiphantes flavipes (Tenfla), Zodarion italicum (Zoda); for carabids: Abax parallelepipedus (Abapar), Asaphidion curtum (Asacur), Calathus fuscipes (Calfus), Harpalus affinis (Haraff), Harpalus atratus (Haratr), Nebria brevicollis (Nebbre), Notiophilus rufipes (Notruf), Pseudoophonus rufipes (Pseruf), Pterostichus madidus (Ptemad); for staphylinids: Aleo. spp, Anotylus inustus (Anoinu), Anthobium atrocephalum (Antatr), Falagrioma thoracica (Faltho), Omalium rivulare (Omariv), Plataraea brunnea (Plabru), Sepedophilus testaceus (Septes), Stenus impressus (Steimp)]. 
Table 2

Taxonomic and functional composition of spider, carabid and staphylinid communities in gardens using partial redundancy analysis (pRDA). Significance level (denoted. $p<0.1$, ${ }^{*} p \leqslant 0.05,{ }^{* *} p \leqslant 0.001,{ }^{* * *} p \leqslant 0.001$ ) are given for the entire model and for each term with an anova like permutation method ( $n=999$ ) (CG/DG, connection to the corridor; Dist $=$ distance to the woodlot, $\mathrm{CMI}=$ connectivity matrix index, Veg = vegetation cover under hedgerows).

\begin{tabular}{|c|c|c|c|c|c|c|}
\hline & \multicolumn{2}{|l|}{ Spider } & \multicolumn{2}{|l|}{ Carabids } & \multicolumn{2}{|l|}{ Staphylinids } \\
\hline & $\begin{array}{l}\text { Taxonomic } \\
\text { composition }\end{array}$ & $\begin{array}{l}\text { Functional } \\
\text { composition }\end{array}$ & $\begin{array}{l}\text { Taxonomic } \\
\text { composition }\end{array}$ & $\begin{array}{l}\text { Functional } \\
\text { composition }\end{array}$ & $\begin{array}{l}\text { Taxonomic } \\
\text { composition }\end{array}$ & $\begin{array}{l}\text { Functional } \\
\text { composition }\end{array}$ \\
\hline $\begin{array}{l}\text { Full } \\
\text { model }\end{array}$ & 1.23 & 0.6 & $2.77^{* *}$ & $2.78^{*}$ & $2.22^{* *}$ & $3.75^{* *}$ \\
\hline Details & & & & & & \\
\hline CG/DG & $1.81^{*}$ & 0.21 & $5.79^{* * *}$ & $2.90^{*}$ & $3.02^{* *}$ & $6.51^{* *}$ \\
\hline Dist & 0.71 & 0.18 & $2.15^{*}$ & 1.42 & 0.88 & 1.63 \\
\hline CMI & 1.31 & 1.77 & $1.91^{*}$ & $5.92^{* *}$ & $2.15^{* *}$ & $6.22^{* *}$ \\
\hline Veg & 0.29 & 0.24 & 1.21 & 2.88 & 0.97 & 0.59 \\
\hline
\end{tabular}

communities with high dispersal capabilities and low affinity to woodlands. For carabids, CG were at an intermediate position along this gradient whereas CG were functionally closer to corridor and sources for staphylinids.

For carabids and staphylinids, the garden analysis confirms that the connection to corridor (CG) and the CMI have positive effect for the habitat affinity and for species with low dispersal capabilities (respectively $p \leqslant 0.01$ and $p \leqslant 0.05$ ) (Fig. S2). We observed a significant effect of the distance to source (Dist) only for carabids.

\section{Discussion}

In this study, we assessed the effectiveness of green corridors, and in a less extent the connectivity of matrices, in enhancing biodiversity of urban domestic gardens. For the three taxa, we found close results on the taxonomic composition. Some differences were observed on functional compositions that could be explained by the dispersal capabilities of the species and by their various responses to landscape structures. Our results provide important information to be applied by land managers for sustainable planning of cities.

\subsection{Positive effects of corridors}

We highlighted that corridors strongly influenced the arthropod metacommunities of the surrounding gardens in urban landscapes and enhanced the dispersal of many species. Indeed, we observed that taxonomic and functional compositions of carabids, staphylinids and spiders communities of CG were closer to those of the corridors and the sources than the communities of DG. We observed identical results for the three taxa that reveal strong underlying general processes in structuring community, such as dispersal limitation (Rosindell et al., 2011; Schweiger et al., 2005). Communities with low dispersal capabilities were associated with sources, corridors and CG, but less for spiders. Moreover, woodland affinity was associated with source, corridors and CG. Because woodland species function mostly in metapopulations (Petit and Burel, 1998), they are more sensitive to fragmentation and thus need corridors more than other species. By enhancing dispersal, corridors not only allow an increase of physical linkage between green spaces, but they also ecologically link green spaces and enhance the functional connectivity of urban landscapes.

For staphylinids, the effect of corridors was found even for species richness and abundance, both lower in DG compared with the other green spaces. Staphylinids are widespread taxa of arthropods that exhibit a great number of species and that seem to be sensitive to fragmentation (Deichsel, 2006; Michaels, 2007) and are particularly interesting for analysing the effects of urbanisation (Bohac, 1999; Deichsel, 2006; Maclvor and Lundholm, 2011). Without corridor connection, the community of staphylinids in DG was composed of few species with strong dispersal capabilities, allowing them to fly over many kilometres in cities (Tomlin et al., 1992). Moreover, source, corridor and CG were characterised by flightless species such as $P$. brunnea. As shown by the garden analysis, connection to corridor mostly explained these results. Contrary to many studies, the vegetation cover described here had a weak effect on arthropod metacommunities (Alaruikka et al., 2002; Le Viol et al., 2008; Niemelä et al., 2002; Small et al., 2003). The low variability of vegetation cover under hedgerows could explain this result. We regrouped many species in Aleo. spp representing $40 \%$ of
$(A)^{*}$

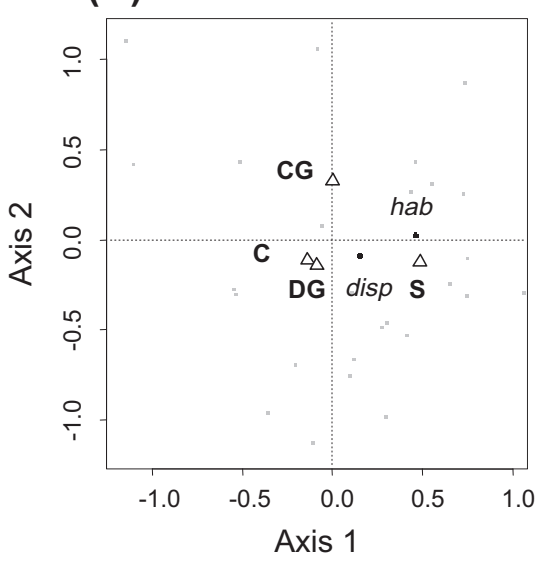

$(B)^{* \star}$

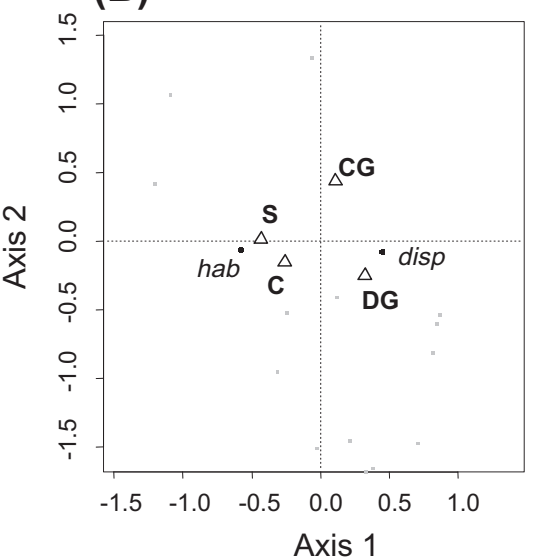

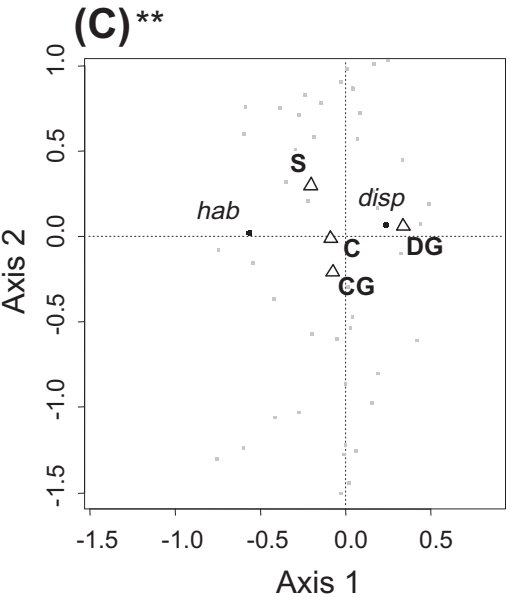

Fig. 3. Partial redundancy analysis (pRDA) biplot illustrating relationship between environmental and species attributes of spider (A), carabid (B) and staphylinid (C) metacommunities. For global analysis, we considered all types of green spaces (white triangle). We considered two species attributes (black dots): dispersal (disp) and affinity to woodland habitat (hab). $p$ values are represented (denoted ${ }^{*} p<0.05,{ }^{* *} p \leqslant 0.01$ ). 
the total abundance, results on species richness of staphylinids should be tempered.

\subsection{Heterogeneous response of taxa to landscape}

Despite the similarity of some of the results, we observed several differences between taxa that could illustrate a heterogeneous response to landscape structure. The role of dispersal and local factors in community structure is an ongoing debate. Niche Assembly Theory considers that local factors and associate processes such as competition or facilitation mainly drive community composition (Gaston and Chown, 2005; Macarthur and Levins, 1967; Massol et al., 2011). In contrast, United Neutral dispersal assembly theory (UNT) highlights the central role of dispersal on shaping metacommunities (Hubbell, 2005; Rosindell et al., 2011).In our study, the sensitivity of metacommunities to isolation effects and, more generally, to landscape structure seems to depend on the dispersal capabilities of species (Goodwin and Fahrig, 2002; Holyoak et al., 2005). For carabids, mechanisms acting at wider scales (e.g., regional scale) and limiting dispersal could explain their rarity (McDonnell and Hahs, 2008; Whittaker et al., 2001). We did not find a lower species richness or abundance in DG for carabids, and they were extremely rare in gardens. In other studies conducted on urban domestic gardens, carabids represent an important part of abundance, for example $18 \%$ of all invertebrates, $60 \%$ of beetles and spiders in (Smith et al., 2006a). The rarity of carabids in gardens could be explained by a "source problem". Indeed, carabids were rare even in sampled woodlots considered as sources for their local properties (e.g., vegetation and size) (a total of 25 species and 421 individuals and only 10 species and 50 individuals of woodland carabids were captured). The role of urbanisation should be investigated as is known to strongly affect the diversity of woodland carabids (Croci et al., 2008; Gaublomme et al., 2008; Magura et al., 2010; Small et al., 2006). As the species richness and abundance of carabids were low in sources, they could not act as sources for propagules and could not be efficiently colonised corridors or, consequently, CG. Thus, the abundance of carabids in gardens was negatively affected by distance to source. Thus, CG close to the source supported more woodland carabids. More studies need to be conducted to clarify the effect of large scale mechanisms on carabids communities (McDonnell and Hahs, 2008; Whittaker et al., 2001).

Our results thus suggest both the importance of dispersal and niche processes in the structure of community (Gaston and Chown, 2005; Mouillot, 2007). We did not find a lower species richness in DG for spider metacommunities. Contrary to carabids, the species richness and abundance of captured spiders were comparable with others works conducted in urban landscapes (Alaruikka et al., 2002). Using ballooning, a majority of spiders can disperse from hundreds metres to hundreds of kilometres (Bell et al., 2005). However, Bonte et al. (2003) suggest that ballooning is negatively linked to the degree of specialisation, especially for woodland species. Thus, corridors may facilitate the dispersal of woodland species between source and connected gardens, but many generalist species coming from other sources could easily reach disconnected gardens, resulting in increased species richness.

Factors at the local scale, such as the composition of habitats, microclimatic conditions or patch area, could strongly shape spider metacommunities (Entling et al., 2007; Le Viol et al., 2008). Sources and gardens are quite different in local conditions. However, we did not find differences on local factors between CG and DG. Works on domestic gardens are still rare, and clear patterns of the effect of local factors have not been identified yet (Smith et al., 2006a). Interspecific competition has been suggested by some authors. For example, as a mechanism to explain spider community structure, interspecific competition could explain the exclusion of gen- eralist species by woodland specialists (Connell, 1983; Wise, 2006) and, in turn, may explain the similar richness detected within CG and DG. For spiders, our results suggest the importance of both dispersal and niche processes in the structure of metacommunities (Gaston and Chown, 2005; Mouillot, 2007). Finally, despite a different taxonomic composition, communities in DG and CG shared a close functional composition. Further analyses focused on spiders and involving more traits were needed to analysed in what extent functional composition of spiders were not by landscape properties.

\subsection{Importance of the urban matrix}

We found that the connectivity of the matrix (CMI) surrounding gardens also shaped the taxonomic and functional composition of carabids and staphylinids. As showed by some authors, matrix properties could play a major role in the landscape connectivity and in corridor efficiency (Baum et al., 2004; Prevedello and Vieira, 2010; Rosenberg et al., 1997). In urban context, the matrix could strongly structure the communities and sometimes overpass species area relationship (Lizée et al., 2011). As showed by their effects on carabid species richness, some elements of the urban matrix as buildings or roads affected the dispersal of ground dwelling species but also of species flying at low altitude (Mader et al., 1990) whereas garden seem less impermeable to the dispersal of those species. Spider communities were not affected by the CMI. The majority of the species mainly present in gardens seem to have high dispersal capabilities and thus were not sensitive to the properties of the matrix.

\subsection{Conclusions and application for landscape planning of cities}

Our results suggest that both the role of corridors and in a less extent the urban matrix are crucial for enhancing biodiversity in urban green spaces such as domestic gardens. Using an indirect measure of spider, carabid and staphylinid dispersal (Jacobson and Peres-Neto, 2010), we show that, as in more natural landscapes, urban green corridors enhance dispersal and limit the effects of isolation by urban matrix. In cities, social and recreational values of corridors are well known (Savard et al., 2000). Ecological role of urban green corridors is supposed by many authors but was rarely clearly identified (Ahern, 2007). This study highlights their ecological role effects in maintaining ordinary biodiversity in highly fragmented landscapes and thus argues for the role of green corridors as an important part of green infrastructure for cities.

Using a multi taxa approach to analyse the effect of fragmentation, we underlined the major role of dispersal capabilities in landscape structure response and, thus, on metacommunity functioning (Hubbell, 1997; Leibold et al., 2004; McKinney, 2006; Rosindell et al., 2011). Processes acting at a wider scale, such as urbanisation, could be responsible for the rarity of some the weak dispersers, such as woodland carabids. Indeed, spiders and staphylinids, most of which have stronger dispersal capabilities than carabids, were abundant in the sources (Alaruikka et al., 2002; Deichsel, 2006). Our results highlight the importance of managing urban landscape at a wider scale and of reconnecting urban green spaces, including houses with domestic garden areas with more natural sources into regional green frameworks.

\section{Acknowledgements}

We thank Fiona Pujalte-Johnson for the language revision. Many thanks to Christine Rollard (MNHN) and Nathalie Devesaux for spider determination and Marc Tronquet for advice on staphylinids determination. We are grateful to Julien Petillon for the dis- 
cussion on spider traits. This study was supported by the French Ministry of the Environment, by the ANR "Trame verte urbaine" and by grants of Ile de France Region. Isabelle Le Viol was supported by SCALES-project (FP7-ENV-2008-1, no.226852).

\section{Appendix A. Supplementary data}

Supplementary data associated with this article can be found, in the online version, at doi:10.1016/j.biocon.2011.11.002.

\section{References}

Ahern, J., 2007. Green infrastructure for cities: The spatial dimension. In: Novotny, Vladimir, Brown, Paul (Eds.), Cities of the Future Towards Integrated Sustainable Water and Landscape Management. IWA Publishers, pp. 267-283.

Alaruikka, D., Kotze, D.J., Matveinen, K., Niemelä, J., 2002. Carabid beetle and spider assemblages along a forested urban-rural gradient in Southern Finland. Journal of Insect Conservation 6, 195-206.

Bailey, S., 2007. Increasing connectivity in fragmented landscapes: an investigation of evidence for biodiversity gain in woodlands. Forest Ecology and Management 238, 7-23.

Bates, D., Maechler, M., 2009. Ime4: Linear mixed-effects models using S4 classes.

Baum, K.A., Haynes, K.J., Dillemuth, F.P., Cronin, J.T., 2004. The matrix enhances the effectiveness of corridors and stepping stones. Ecology 85, 2671-2676.

Bell, J.R., Bohan, D.A., Shaw, E.M., Weyman, G.S., 2005. Ballooning dispersal using silk: world fauna, phylogenies, genetics and models. Bulletin of Entomological Research 95, 69-114.

Blair, R., Johnson, E., 2008. Suburban habitats and their role for birds in the urbanrural habitat network: points of local invasion and extinction? Landscape Ecology 23, 1157-1169.

Bohac, J., 1999. Staphylinid beetles as bioindicators. Agriculture, Ecosystems \& Environment 74, 357-372.

Bolker, B.M., Brooks, M.E., Clark, C.J., Geange, S.W., Poulsen, J.R., Stevens, M.H.H., White, J.-S.S., 2009. Generalized linear mixed models: a practical guide for ecology and evolution. Trends in Ecology and Evolution 24, 127-135.

Bonte, D., Vandenbroecke, N., Lens, L., Maelfait, J.-P., 2003. Low propensity for aerial dispersal in specialist spiders from fragmented landscapes. Proceedings: Biological Sciences 270, 1601-1607.

Chapman, J.W., Reynolds, D.R., Smith, A.D., Riley, J.R., Telfer, M.G., Woiwod, I.P., 2005. Mass aerial migration in the carabid beetle Notiophilus biguttatus. Ecological Entomology 30, 264-272.

Chave, J., 2004. Neutral theory and community ecology. Ecology Letters 7, 241-253.

Clergeau, P., 2007. Une écologie du paysage urbain. Apogée, Rennes, France.

Collinge, S.K., 1996. Ecological consequences of habitat fragmentation: implications for landscape architecture and planning. Landscape and Urban Planning 36, 5977.

Connell, J.H., 1983. On the prevalence and relative importance of interspecific competition: evidence from field experiments. The American Naturalist 122 , 661-696.

Croci, S., Butet, A., Georges, A., Aguejdad, R., Clergeau, P., 2008. Small urban woodlands as biodiversity conservation hot-spot: a multi-taxon approach. Landscape Ecology 23, 1171-1186.

Davies, Z.G., Fuller, R.A., Loram, A., Irvine, K.N., Sims, V., Gaston, K.J., 2009. A national scale inventory of resource provision for biodiversity within domestic gardens. Biological Conservation 142, 761-771.

Davies, Z.G., Pullin, A.F., 2007. Are hedgerows effective corridors between fragments of woodland habitat? An evidence-based approach. Landscape Ecology 22, 333351

Deichsel, R., 2006. Species change in an urban setting-ground and rove beetles (Coleoptera: Carabidae and Staphylinidae) in Berlin. Urban Ecosystems 9, 161178.

Desender, K., Small, E., Gaublomme, E., Verdyck, P., 2005. Rural-urban gradients and the population genetic structure of woodland ground beetles. Conservation Genetics 6, 51-62.

Didham, R.K., Basset, Y., Leather, S.R., 2010. Research needs in insect conservation and diversity. Insect Conservation and Diversity 3, 1-4.

Entling, W., Schmidt, M.H., Bacher, S., Brandl, R., Nentwig, W., 2007. Niche properties of Central European spiders: shading, moisture and the evolution of the habitat niche. Global Ecology and Biogeography 16, 440-448.

Faraway, J.J., 2006. Extending the Linear Model with R. Generalized Linear, Mixed Effects and Nonparametric Regression Models. Chapman \& Hall/CRC.

Fattorini, S., 2011. Insect extinction by urbanization: a long term study in Rome. Biological Conservation 144, 370-375.

Gaston, K.J., Chown, S.L., 2005. Neutrality and the niche. Functional Ecology 19, 1-6.

Gaublomme, E. Hendrickx, F. Dhuyvetter, H. Desender, K, 2008. The effects of forest patch size and matrix type on changes in carabid beetle assemblages in an urbanized landscape. Biological Conservation 141, 2585-2596.

Gibb, H., Hochuli, D.F., 2002. Habitat fragmentation in an urban environment: large and small fragments support different arthropod assemblages. Biological Conservation 106, 91-100.

Gilbert-Norton, L., Wilson, R., Stevens, J.R., Beard, K.H., 2010. A meta-analytic review of corridor effectiveness. Conservation Biology 24, 660-668.
Goddard, M.A., Dougill, A.J., Benton, T.G., 2010. Scaling up from gardens: biodiversity conservation in urban environments. Trends in Ecology and Evolution 25, 90-98.

Good, J.A., Giller, P.S., 1991. The effect of cereal and grass management on staphylinid (Coleoptera) assemblages in South-West Ireland. Journal of Applied Ecology 28, 810-826.

Goodwin, B.J., Fahrig, L., 2002. How does landscape structure influence landscape connectivity? Oikos 99, 552-570.

Griffiths, G.J.K., Winder, L., Holland, J.M., Thomas, C.F.G., Williams, E., 2007. The representation and functional composition of carabid and staphylinid beetles in different field boundary types at a farm-scale. Biological Conservation 135, 145-152.

Hamer, A.J., McDonnell, M.J., 2008. Amphibian ecology and conservation in the urbanising world: a review. Biological Conservation 141, 2432-2449.

Harvey, J.A., Nellist, D.R., Telfer, M.G., 2002. Provisional Atlas of British Spiders (Arachnida, Araneae). Biological Records Centre, Wallingford, UK.

Holyoak, M., Mathew, A., leibold, M.A., 2005. Metacommunities: spatial dynamics and ecological communities. The University of Chicago Press, Chicago.

Hubbell, S.P., 1997. A unified theory of biogeography and relative species abundance and its application to tropical rain forests and coral reefs. Coral Reefs 16, S9-S21.

Hubbell, S.P., 2005. Neutral theory in community ecology and the hypothesis of functional equivalence. Functional Ecology 19, 166-172.

Jacobson, B., Peres-Neto, P., 2010. Quantifying and disentangling dispersal in metacommunities: how close have we come? How far is there to go? Landscape Ecology 25, 495-507.

Jongman, R.H.G., Külvik, M., Kristiansen, I., 2004. European ecological networks and greenways. Landscape and Urban Planning 68, 305-319.

Joyce, K.A., Holland, J.M., Doncaster, C.P., 1999. Influences of hedgerow intersections and gaps on the movement of carabid beetles. Bulletin of Entomological Research 89, 523-531.

Kerr, J.T., Ostrovsky, M., 2003. From space to species: ecological applications for remote sensing. Trends in Ecology \& Evolution 18, 299-305.

Lavorel, S., Grigulis, K., McIntyre, S., Williams, N.S.G., Garden, D., Dorrough, J., Berman, S., Quétier, F., Thébault, A., Bonis, A., 2008. Assessing functional diversity in the field - methodology matters! Functional Ecology 22, 134-147.

Le Viol, I., Julliard, R., Kerbiriou, C., de Redon, L., Carnino, N., Machon, N., Porcher, E., 2008. Plant and spider communities benefit differently from the presence of planted hedgerows in highway verges. Biological Conservation 141, 1581-1590.

Legendre, P., Anderson, M.J., 1999. Distance-based redundancy analysis: testing multispecies responses in multifactorial ecological experiments. Ecological Monographs 69, 1-24.

Legendre, P., Gallagher, E., 2001. Ecologically meaningful transformations for ordination of species data. Oecologia 129, 271-280.

Leibold, M.A., Holyoak, M., Mouquet, N., Amarasekare, P. Chase, J.M., Hoopes, M.F., Holt, R.D., Shurin, J.B., Law, R., Tilman, D., Loreau, M., Gonzalez, A., 2004. The metacommunity concept: a framework for multi-scale community ecology. Ecology Letters 7, 601-613.

Lizée, M.-H., Manel, S., Mauffrey, J.-F., Tatoni, T., Deschamps-Cottin, M., 2011. Matrix configuration and patch isolation influences override the species - area relationship for urban butterfly communities. Landscape Ecology 1, 11. doi:10.1007/s10980-011-9651-x.

Loram, A., Tratalos, J., Warren, P., Gaston, K., 2007. Urban domestic gardens (X): the extent \& structure of the resource in five major cities. Landscape Ecology 22, 601-615.

Macarthur, R., Levins, R., 1967. The limiting similarity, convergence, and divergence of coexisting species. The American Naturalist 101, 377-385.

MacIvor, J., Lundholm, J., 2011. Insect species composition and diversity on intensive green roofs and adjacent level-ground habitats. Urban Ecosystems $14,225-241$

Mader, H.J., Schell, C., Kornacker, P., 1990. Linear barriers to arthropod movements in the landscape. Biological Conservation 54, 209-222.

Magura, T., Lovei, G.L., Tothmeresz, B., 2008. Time-consistent rearrangement of carabid beetle assemblages by an urbanisation gradient in Hungary. In Acta Oecologica-International Journal of Ecology, 233-243.

Magura, T., Lövei, G.L., Tóthmérész, B., 2010. Does urbanization decrease diversity in ground beetle (Carabidae) assemblages? Global Ecology and Biogeography 19, $16-26$.

Markgraf, A., Basedow, T., 2002. Flight activity of predatory Staphylinidae in agriculture in central Germany. Journal of Applied Entomology-Zeitschrift Fur Angewandte Entomologie 126, 79-81.

Massol, F., Gravel, D., Mouquet, N., Cadotte, M.W., Fukami, T., Leibold, M.A., 2011. Linking community and ecosystem dynamics through spatial ecology. Ecology Letters 14, 313-323.

McDonnell, M., Hahs, A., 2008. The use of gradient analysis studies in advancing our understanding of the ecology of urbanizing landscapes: current status and future directions. Landscape Ecology 23, 1143-1155.

McGarigal, K., Cushman, S.A., 2002. Comparative evaluation of experimental approaches to the study of habitat fragmentation effects. Ecological Applications 12, 335-345.

McGarigal, K.e.a., 2002. Fragstats: Spatial Pattern Analysis Program for Categorical Maps. University of Massachusetts. <www.umass.edu/landeco/research. fragstats/fragstats.html>.

McIntyre, N.E., Rango, J., Fagan, W.F., Faeth, S.H., 2001. Ground arthropod community structure in a heterogeneous urban environment. Landscape and Urban Planning 52, 257-274. 
McKinney, M., 2008. Effects of urbanization on species richness: a review of plants and animals. Urban Ecosystems 11, 161-176.

McKinney, M.L., 2006. Urbanization as a major cause of biotic homogenization. Biological Conservation 127, 247-260.

Michaels, K.F., 2007. Using staphylinid and tenebrionid beetles as indicators of sustainable landscape management in Australia: a review. Australian Journal of Experimental Agriculture 47, 435-449.

Mouillot, D., 2007. Niche-assembly vs. dispersal-assembly rules in coastal fish metacommunities: implications for management of biodiversity in brackish lagoons. Journal of Applied Ecology 44, 760-767.

Niemelä, J., Johan Kotze, D., Venn, S., Penev, L., Stoyanov, v., Spence, J., Hartley, D. Montes de Oca, E., 2002. Carabid beetle assemblages (Coleoptera, Carabidae) across urban-rural gradients: an international comparison. Landscape Ecology 17, 387-401.

Noda, T., 2004. Spatial hierarchical approach in community ecology: a way beyond high context-dependency and low predictability in local phenomena. Population Ecology 46, 105-117.

Nyffeler, M., Sunderland, K.D., 2003. Composition, abundance and pest control potential of spider communities in agroecosystems: a comparison of European and US studies. Agriculture, Ecosystems \& Environment 95, 579-612.

Pauchard, A., Aguayo, M., Peña, E., Urrutia, R., 2006. Multiple effects of urbanization on the biodiversity of developing countries: the case of a fast-growing metropolitan area (Concepcion, Chile). Biological Conservation 127, 272-281.

Petit, S., Burel, F., 1998. Connectivity in fragmented populations: Abax parallelepipedus in a hedgerow network landscape. Comptes Rendus de l'Académie des Sciences - Series III - Sciences de la Vie 321, 55-61.

Prevedello, J.A., Vieira, M.V., 2010. Does the type of matrix matter? A quantitative review of the evidence. Biodiversity and Conservation 19, 1205-1223.

Ribera, I., Dolédec, S., Downie, I.S., Foster, G.N., 2001. Effect of land disturbance and stress on species traits of ground beetle assemblages. Ecology 82, 1112-1129.

Rosenberg, D.K., Noon, B.R., Meslow, E.C., 1997. Biological corridors: Form, function, and efficacy. Bioscience 47, 677-687.

Rosindell, J., Hubbell, S.P., Etienne, R.S., 2011. The unified neutral theory of biodiversity and biogeography at age ten. Trends in Ecology and Evolution 26 340-348.
Savard, J.-P.L., Clergeau, P., Mennechez, G., 2000. Biodiversity concepts and urban ecosystems. Landscape and Urban Planning 48, 131-142.

Schweiger, O., Maelfait, J.P., Van Wingerden, W., Hendrickx, F., Billeter, R. Speelmans, M., Augenstein, I., Aukema, B., Aviron, S., Bailey, D., Bukacek, R., Burel, F., DiekÖTter, T., Dirksen, J., Frenzel, M., Herzog, F., Liira, J., Roubalova, M., Bugter, R., 2005. Quantifying the impact of environmental factors on arthropod communities in agricultural landscapes across organizational levels and spatial scales. Journal of Applied Ecology 42, 1129-1139.

Small, E., Sadler, J.P., Telfer, M., 2006. Do landscape factors affect brownfield carabid assemblages? Science of the Total Environment 360, 205-222.

Small, E.C., Sadler, J.P., Telfer, M.G., 2003. Carabid beetle assemblages on urban derelict sites in Birmingham, UK. Journal of Insect Conservation 6, 233-246.

Smith, R., Gaston, K., Warren, P., Thompson, K., 2006a. Urban domestic gardens (VIII): environmental correlates of invertebrate abundance. Biodiversity and Conservation 15, 2515-2545.

Smith, R.M., Thompson, K., Hodgson, J.G., Warren, P.H., Gaston, K.J., 2006b. Urban domestic gardens (IX): Composition and richness of the vascular plant flora, and implications for native biodiversity. Biological Conservation 129, 312-322.

Thomas, C.F.G., Parkinson, L., Griffiths, G.J.K., Garcia, A.F., Marshall, E.J.P., 2001 Aggregation and temporal stability of carabid beetle distributions in field and hedgerow habitats. Journal of Applied Ecology 38, 100-116.

Tomlin, A., McLeod, D., Moore, L., Whistlecraft, J., Miller, J., Tolman, J., 1992. Dispersal of Aleochara bilineata [Col.: Staphylinidae] following inundative releases in urban gardens. BioControl 37, 55-63.

Whittaker, R.J., Willis, K.J., Field, R., 2001. Scale and species richness: towards a general, hierarchical theory of species diversity. Journal of Biogeography 28 453-470.

Wilson, D.S., 1992. Complex interactions in metacommunities, with implications for biodiversity and higher levels of selection. Ecology 73, 1984-2000.

Wise, D.H., 2006. Cannibalism, food limitation, intraspecific competition, and the regulation of spider populations. Annual Review of Entomology 51, 441-465.

Yuan, F., Bauer, M.E., 2007. Comparison of impervious surface area and normalized difference vegetation index as indicators of surface urban heat island effects in Landsat imagery. Remote Sensing of Environment 106, 375-386. 